\title{
Orchard Grass Pollen IgA Measurement
}

National Cancer Institute

\section{Source}

National Cancer Institute. Orchard Grass Pollen IgA Measurement. NCI Thesaurus. Code C130081.

A measurement of the orchard grass (Dactylis glomerata) pollen IgA in a biological specimen. 